\title{
Growth dynamics of rubber tree clones in northwestern Minas Gerais, Brazil
}

\author{
Dinâmica de crescimento de clones de seringueira na região noroeste de Minas Gerais
}

\author{
Maria Isabela da Costa Terra ${ }^{\mathrm{I}}$ Flora Ferreira Camargo ${ }^{\mathrm{II}}$ Renato Luiz Grisi Macedo ${ }^{\text {II }}$ \\ Bruna Anair Souto Dias" Nelson Venturin ${ }^{\text {II }}$ Erick Martins NieriI
}

\section{ABSTRACT}

This study aimed to evaluate the growth of rubber tree clones (Hevea brasiliensis (Willd.exA.Juss.) Müll. Arg.) in the Northwest region of Minas Gerais, Brazil. Randomized blocks, constituted of three treatments (rubber tree clones) and four repetitions were used, and evaluated as plots subdivided in time. Subplots represent the evaluations carried out at the ages 62 , 77, 87, 99, 113 and 128 months after planting. It was evaluated survival, stem circumference and total plant height. Current annual increment and average annual increment of circumference and also the number of trees fit for rubber tapping were calculated. Results obtained indicate that clones GT 1, IAN 2880, IAC 15, RRIM 600, PB 235 and IAN 3156 have potential to establish under local edaphoclimatic conditions. Increase in plant height and stem circumference throughout the evaluation period makes it evident that the clones have different growing paces in the studied region. Clones GT 1, IAN 3087, IAN 3156 and PR 255 had larger stalk circumference at 128 months, and $P R 255$ was the only one fit for rubber tapping at the age of 128 months after planting.

Key words: forestry, savannah, rubber cultivation, introduction of forest species.

\section{RESUMO}

Objetivou-se no presente estudo avaliar o comportamento e o crescimento de clones de seringueira (Hevea brasiliensis (Willd. ex A. Juss.) Müll. Arg.) introduzidos na região noroeste do estado de Minas Gerais. $O$ delineamento utilizado foi o de blocos casualizados, constituido por 12 clones de seringueira, quatro repetições, avaliadas em esquema de parcelas subdivididas no tempo: aos 62, 77, 87, 99, 113 e 128 meses após o plantio. Foram avaliadas a sobrevivência, a circunferência $e$ altura total da planta. A partir dessas informações, foram calculados $o$ incremento corrente anual e o incremento médio anual da variável circunferência, e o número de árvores aptas à sangria.
Os resultados obtidos indicaram que os clones GT 1, IAN 2880, IAC 15, RRIM 600, PB 235 e IAN 3156 apresentam potencial de estabelecimento às condições edafoclimáticas da região. $O$ crescimento em altura e circunferência ao longo do periodo de avaliação evidencia que os clones de seringueira apresentam diferentes ritmos de crescimento na região de estudo. Os clones GT 1, IAN 3087, IAN 3156 e PR 255 foram os que apresentaram maior circunferência de caule aos 128 meses, sendo o clone PR 255 o único clone apto à sangria aos 128 meses de idade após o plantio.

Palavras-chave: silvicultura, cerrado, heveicultura, introdução de espécie florestal.

\section{INTRODUCTION}

The rubber tree is a native species from Amazon forest. After the commercial plantation in the region failed, because of, among other factors, leaf blight (favored by the characteristic high humidity), and the high demand for natural rubber, the plantation expanded to other places in the country, including southeastern Brazil, as a promising alternative (FURTADO, 2007). However, this expansion was not enough to supply the national demand of this material. According to VILELA \& ARAÚJO (2006) the national production in 2030 won't be enough to supply our consumption, estimated in more than 600 thousand tons (3\% per year rate) and according to the International Rubber Study Group (IRSG) the expected is a global deficit of 4 million tons of natural rubber in 2035 (ROSSMANN et al. 2005).

\footnotetext{
IMinistério do Desenvolvimento Agrário (MDA), Delegacia Federal do Desenvolvimento Agrário, Belo Horizonte, MG, Brasil.

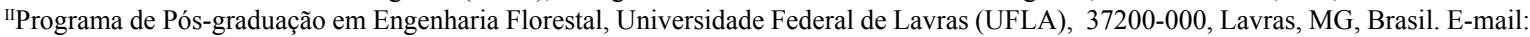
floracamargo@hotmail.com. *Corresponding author.

IIICampus Professora Cinobelina Elvas (CPCE), Universidade Federal do Piauí (UFPI), Bom Jesus, PI, Brasil. 
In search for self-sufficiency in national production of natural rubber the evaluation of clones is an important step. For the specific weather condition of the zoned territory for rubber tree in Brazil, it is essential to test clones that show required adaptability and ideal productivity (PEREIRA \& PEREIRA, 2001). Minas Gerais accounts for approximately $6,1 \%$ of national production (IBGE, 2012), with plantations concentrated in the Triangulo Mineiro and Alto Paranaiba (MESQUITA,2006). There is a high demand for information and research on the behavior of clones and their suitability to other meso regions of the state. The analysis of the establishment potential evaluated at first through survival rate and initial growth of the clones after plantation in field can be a good indicative of adaptation in a specific region, considering local soil and weather variations. It should be the first step in defining the most productive and plague resistant clones.

Several authors showed results obtained in several regions, mainly in São Paulo State (GONÇALVES et al., 2000; GONÇALVES et al., 2001; GONÇALVES et al., 2002; CAVALCANTE \& CONFORTO, 2002; GONÇALVES et al., 2003; VERARDI, 2009; CONFORTO et al., 2015). Some clones may present slow initial growth and then develop quickly; later growth stages (MACEDO et al., 2002). This increases the need to follow the height growth of clones in a new introduction area; however, it is clear from the literature that the researches that follow the growth dynamics after the first years of establishment are very limited. This researched aimed to evaluate the development of 12 rubber tree clones in northwestern Minas Gerais, in order to evaluate their behavior through biometric variables and survival in culture conditions in the town of Paracatu from 62 to 128 months. Considering the hypothesis that the genetic difference of the clones can insure differentiated performance, this study is justified by the absence of scientific information, comparing different clones in the town of Paracatu, MG.

\section{MATERIALS AND METHODS}

The experiment was set in Riacho Farm $\left(17^{\circ} 36^{\prime} \mathrm{S}\right.$ e $46^{\circ} 42^{\prime} \mathrm{W}$, average altitude $\left.550 \mathrm{~m}\right)$, in Paracatu, northwestern Minas Gerais. The weather in the region is humid tropical savanna, with dry winter and rainy summer, type Aw, according to Köppen classification. Annual average temperature is $22.6^{\circ} \mathrm{C}$ (monthly average of $18^{\circ} \mathrm{C}$ in the coldest season and $29,1^{\circ} \mathrm{C}$ in the warmest). Annual average rainfall is $1,450 \mathrm{~mm}$, with monthly average rainfall under $60 \mathrm{~mm}$ in the driest months. Predominant soil in the area is yellow-red dystrophic oxisol (the experimental field was previously used as bovine pasture, with growth of Urochloa spp. (Brachiaria). To implement the experiment, soil was prepared with deep plowing and two leveling harrowing. The correction fertilization was done with $240 \mathrm{~kg}$ natural phosphate and $120 \mathrm{~kg}$ plaster per hectare applied and incorporate to the soil in all experimental area. The rubber tree clonal seedlings were formed by grafting. Holes were previously fertilized with $150 \mathrm{~g}$ of N-P-K 06-30-06 and basins were formed around the holes to favor water catchment and storage. Other forestry and phytosanitary measures were carried out until three year growth, according to technical recommendation, and then the experimental area was fenced.

A randomized block design was used, with measurements repeated in time. Twelve rubber-tree clones (PB 235, PR 255, IAN 3193, IAN 3087, IAN 3156, IAN 2880, RRIM 600, RRIM 701, PR 107, IAC 15, IPA 1 and GT 1) were allocated randomly with the plots and we established subplots for the evaluations performed at $62,77,87,99,113$ and 128 months after plantation. Planting lines (blocks) were oriented East-West and each plot consisted of eight clonal rubber-trees, planted using a $10 \times 2 \mathrm{~m}$ spacing. Each plant had a $20 \mathrm{~m}^{2}$ space. Six plants were effectively measured in each plot because the first and the last plants in the planting line were considered part of the edge and were not measured.

Survival (S) was evaluated through counting of living plants in each parcel; circumference (C) was measured with a measure tap, and total plan height $(\mathrm{H})$ with a hypsometric rule. Results are presented in percentages, centimeters and meters, respectively. It was also calculated the circumference current annual increment (ICAC) and mean annual increment (IMAC) and the number of plants suitable for bleeding (SAN) determined by the standard value of the country, $45 \mathrm{~cm}$ of stem perimeter at $1.30 \mathrm{~cm}$ from the soil, this parameter guides the decision about the maturity degree of the plantation (SAA, 2010).

When needed, data were transformed and submitted again to analysis of the assumptions above according to suggestion of STEEL et al. (1997). Later the data were submitted to variance analysis (ANOVA) according to the same authors, and when it was verified a difference among the clones through $\mathrm{F}$ test at $5 \%$ probability Scott-Knott average test was applied. To variance analysis execution it was used the software SISVAR 5.3 (FERREIRA, 2010). 


\section{RESULTS AND DISCUSSIONS}

Preliminary studies on the establishment potential of the clones carried out by MACEDO et al. (2002) and MACEDO et al. (2009) were used as benchmarks for this research. There was significant difference, between clones, which indicates the existence of variability for most analyzed variables, except IMAC. Interaction presence between clones and ages reveals a high variability in every analyzed variable in different ages. For blocks, it wasn't observed and significant effect on height and survival (Table 1). Survival, circumference and height variance coefficients $(\mathrm{CV})$ are equivalent to the ones reported by MACEDO et al. (2009), which are stated as normal for field experiments. Thus, the potential analysis established, evaluated through survival and initial growth in the field, may be a good indicator of a clones or species adaptation to a specific region.

Constant survival throughout the evaluated time was observed, except for clones PR255 and PR107. Clones with the highest survival were GT 1, IAN 2880, IAC 15 and RRIM 600 (Table 2), agreeing with the studies by MESQUITA (2006) which showed the best adaptability to clone RRIM600 in southern Minas Gerais, and by GONÇALVES (1999), which showed elevated adaptability to clone GT1 in a study carried out in São Paulo State.

It can be noticed in table 2 that the clones PR 255 and IAN 3156 were the ones with highest growth of the stem circumference in the last evaluation, at 128 months growth, with $46,49 \mathrm{~cm}$ and 45,40cm, respectively. Conversely, clones PB 235 and IPA 1 suffered stagnation in growth, kept over time. The good stem growth performance of the clone IAN 3156 was also reported by GONÇALVES et al. (2001a), in São Paulo's plateau. These authors highlighted this clone as the most vigorous among the studied, with an average stem circumference of $62,5 \mathrm{~cm}$, at 10 years old, suggesting the large scale experimentation in several environments in São Paulo.

Stem circumference growth and stem thickness are two useful characteristics to guide the section for yield and vigor. Just the clones PR 255 and IAN 3156 presented circumference large enough to start bleeding at 128 month growth (Table 2). It can be observed the rubber tree clones that started showing stem perimeter of $45 \mathrm{~cm}$; they were IAN 3087 and PRIM 701 at 87 months, and IAN 3193, IPA 1 and IAC 15 at 128 month growth (Table 3). In studies carried out by GONÇALVES et al. (2006) it was noticed that 10 years after plantation, $83 \%$ of the clone trees RRIM 600 and PR107 were able to be bled, values superior to the ones obtained at this experiment $(29,17 \%$ for RRIM 600 and $20,83 \%$ got PR 107).

Analyzing the amazon clones, it is noticed the potential of clone IAN 3087, which presented at 99 months the highest perceptual of bleeding able trees among the studied clones $(29,17 \%)$ (Table 3 ). This value is consistent with the results found by ALVES et al. (1982), who evaluated the potential of some clone in Pará State, with $30 \%$ of IAN 3087

Table 1 - Variance analyses with mean squares for survival (S), height $(\mathrm{H})$, stem circumference $(\mathrm{C})$, annual current circumference incremen1 (ICAC), annual mean circumference increment (IMAC), number of trees suitable for bleeding (SAN) of clones of (Hevea brasiliensis (Willd. ex A. Juss.) Müell.Arg.) evaluate at 62, 77, 87, 99, 113 e 128 months after plantation in Paracatu, MG.

\begin{tabular}{|c|c|c|c|c|c|c|c|}
\hline \multirow{2}{*}{ Variation Source } & \multirow{2}{*}{ GL } & \multicolumn{6}{|c|}{ - } \\
\hline & & $\mathrm{S}$ & $\mathrm{H}$ & $\mathrm{C}$ & ICAC & IMAC & SAN \\
\hline Clone & 11 & $0.70^{*}$ & $14.21^{*}$ & $234.71^{*}$ & $11.06^{*}$ & $3.57 \mathrm{~ns}$ & $13.73^{*}$ \\
\hline Repetition & 3 & $0.27 \mathrm{~ns}$ & $4.66 \mathrm{~ns}$ & $462.95^{*}$ & $58.36^{*}$ & $5.96^{*}$ & $32.73^{*}$ \\
\hline Residue (a) & 33 & 0.297010 & 6.293835 & 108.307945 & 3.335041 & 1.801221 & 5.125552 \\
\hline Age & 5 & $0.01 \mathrm{~ns}$ & $217.14^{*}$ & $2178.28^{*}$ & $69.24^{*}$ & $1.27 \mathrm{~ns}$ & $100.33^{*}$ \\
\hline Residue (b) & 15 & 0.003788 & 0.490009 & 52.244121 & 10.131516 & 0.530503 & 7.614868 \\
\hline Clone x Age & 55 & $0.01^{*}$ & $0.66^{*}$ & $8.71^{*}$ & $3.28^{*}$ & $0.08^{*}$ & $3.23^{*}$ \\
\hline Residue (c) & 165 & 0.002715 & 0.238813 & 2.483060 & 1.747243 & 0.039028 & 1.501799 \\
\hline CV a (\%) & & 38.98 & 26.48 & 33.87 & 55.85 & 34.08 & 101.06 \\
\hline $\mathrm{CV}$ b (\%) & & 4.40 & 7.39 & 23.52 & 97.35 & 18.50 & 123.19 \\
\hline $\mathrm{CV}$ c $(\%)$ & & 3.73 & 5.16 & 5.13 & 40.43 & 5.02 & 54.71 \\
\hline
\end{tabular}

${ }^{*}(\mathrm{P} \leq 0.05)$ through $\mathrm{F}$ test; ns $(\mathrm{P}>0.05)$ through $\mathrm{F}$ test. 
Table 2 - Height average (m), Stem circumference averages (cm) and rubber tree (Hevea brasiliensis (Willd. ex A. Juss.) Müell.Arg.) survival percentage, related to the studied clones and evaluation time, Paracatu, MG.

\begin{tabular}{|c|c|c|c|c|c|c|c|c|c|c|c|c|c|c|c|}
\hline \multirow[t]{2}{*}{ Clones } & \multicolumn{6}{|c|}{----------62 months--------- ---------77 months-------- } & \multicolumn{6}{|c|}{ - ---87 months--- } & \multicolumn{3}{|c|}{---------128 months--------- } \\
\hline & $\mathrm{H}^{1}$ & $\mathrm{C}^{2}$ & $\mathrm{~S}^{3}$ & $\mathrm{H}^{1}$ & $\mathrm{C}^{2}$ & $\mathrm{~S}^{3}$ & $\mathrm{H}^{1}$ & $\mathrm{C}^{2}$ & $\mathrm{~S}^{3}$ & $\mathrm{H}^{1}$ & $\mathrm{C}^{2}$ & $\mathrm{C}^{2}$ & $\mathrm{H}^{1}$ & $\mathrm{C}^{2}$ & $\mathrm{~S}^{3}$ \\
\hline IAN 3087 & $5.76 \mathrm{c}$ & $24.06 \mathrm{a}$ & $66.7 \mathrm{e}$ & $6.31 \mathrm{~d}$ & $29.96 \mathrm{a}$ & $66.67 \mathrm{e}$ & $7.63 \mathrm{e}$ & $33.40 \mathrm{a}$ & $66.67 \mathrm{e}$ & $8.16 \mathrm{~d}$ & $37.50 \mathrm{a} 66.67 \mathrm{e}$ & 9.74 e 39.35 b66.67 e & $10.56 \mathrm{~d}$ & $42.68 \mathrm{~b}$ & $66.67 \mathrm{e}$ \\
\hline IPA 1 & $6.36 \mathrm{c}$ & $22.53 \mathrm{a}$ & $83.33 \mathrm{~d}$ & $7.29 \mathrm{c}$ & $25.64 \mathrm{~b}$ & $83.33 \mathrm{~d}$ & $9.11 \mathrm{c}$ & $30.28 \mathrm{~b}$ & $83.33 \mathrm{~d}$ & $10.67 \mathrm{~b}$ & $35.01 \mathrm{~b} 83.33 \mathrm{~d}$ & $11.34 \mathrm{c} 39.19 \mathrm{~b} 83.33 \mathrm{~d}$ & $11.98 \mathrm{c}$ & $43.78 \mathrm{~b}$ & $83.33 \mathrm{~d}$ \\
\hline IAN 3193 & $6.41 \mathrm{c}$ & $22.07 \mathrm{a}$ & $87.50 \mathrm{~d}$ & $7.13 \mathrm{c}$ & $27.68 \mathrm{a}$ & $87.50 \mathrm{~d}$ & $8.81 \mathrm{~d}$ & $31.15 \mathrm{~b}$ & $87.50 \mathrm{~d}$ & $9.12 \mathrm{c}$ & $34.29 \mathrm{~b} 87.50 \mathrm{~d}$ & $10.42 \mathrm{~d} 35.82 \mathrm{c} 87.50 \mathrm{~d}$ & $11.65 \mathrm{c}$ & $38.08 \mathrm{~d}$ & $87.50 \mathrm{~d}$ \\
\hline RRIM 701 & $6.49 \mathrm{c}$ & $21.98 \mathrm{a}$ & $87.50 \mathrm{c}$ & $7.33 \mathrm{c}$ & $28.42 \mathrm{a}$ & $87.50 \mathrm{~d}$ & $8.42 \mathrm{~d}$ & $32.88 \mathrm{a}$ & $87.50 \mathrm{~d}$ & $9.08 \mathrm{c}$ & $37.54 \mathrm{a} 87.50 \mathrm{~d}$ & $10.45 \mathrm{~d} 41.26 \mathrm{a} 87.50 \mathrm{~d}$ & $11.40 \mathrm{c}$ & $45.40 \mathrm{a}$ & $87.50 \mathrm{~d}$ \\
\hline IAN 3156 & $6.61 \mathrm{c}$ & $21.09 \mathrm{a}$ & $91.67 \mathrm{~b}$ & $7.48 \mathrm{c}$ & $26.17 \mathrm{~b}$ & $91.67 \mathrm{~b}$ & $9.93 \mathrm{~b}$ & $30.23 \mathrm{~b}$ & $91.67 \mathrm{~b}$ & $10.89 \mathrm{~b}$ & $34.75 \mathrm{~b} 91.67 \mathrm{~b}$ & $12.92 \mathrm{a} 37.01 \mathrm{c} 91.67 \mathrm{~b}$ & $14.31 \mathrm{a}$ & $39.92 \mathrm{c}$ & $91.67 \mathrm{~b}$ \\
\hline PB 235 & $6.73 \mathrm{c}$ & $21.08 \mathrm{a}$ & $95.83 \mathrm{~b}$ & $7.08 \mathrm{c}$ & $24.46 \mathrm{c}$ & $95.83 \mathrm{~b}$ & $8.28 \mathrm{~d}$ & $28.22 \mathrm{c}$ & $95.83 \mathrm{~b}$ & $9.06 \mathrm{c}$ & $32.00 \mathrm{c} 95.83 \mathrm{~b}$ & $10.84 \mathrm{c} 34.00 \mathrm{~d} 95.83 \mathrm{~b}$ & $12.33 \mathrm{c}$ & $37.00 \mathrm{~d}$ & $95.83 \mathrm{~b}$ \\
\hline PR 255 & $6.82 \mathrm{~b}$ & $20.89 a$ & $95.83 \mathrm{~b}$ & $8.04 \mathrm{~b}$ & $27.93 \mathrm{a}$ & $95.83 \mathrm{~b}$ & $9.26 \mathrm{c}$ & $33.71 \mathrm{a}$ & $87.50 \mathrm{c}$ & $10.10 \mathrm{~b}$ & $38.91 \mathrm{a} 87.50 \mathrm{c}$ & $11.14 \mathrm{c} 42.21 \mathrm{a} 87.50 \mathrm{c}$ & $11.91 \mathrm{c}$ & 46.49 a & $87.50 \mathrm{c}$ \\
\hline RRIM 600 & $6.99 \mathrm{~b}$ & $20.27 b$ & $100 \mathrm{a}$ & $7.77 \mathrm{~b}$ & $26.19 \mathrm{~b}$ & $100 \mathrm{a}$ & $9.56 \mathrm{c}$ & $29.19 \mathrm{c}$ & $100 \mathrm{a}$ & $10.36 \mathrm{~b}$ & $33.64 \mathrm{~b} 100 \mathrm{a}$ & $12.12 \mathrm{~b} 35.93 \mathrm{c} 100 \mathrm{a}$ & $13.10 \mathrm{~b}$ & $39.35 \mathrm{c}$ & $100 \mathrm{a}$ \\
\hline IAC 15 & $7.06 \mathrm{~b}$ & $19.89 \mathrm{~b}$ & $100 \mathrm{a}$ & $7.41 \mathrm{c}$ & $22.65 \mathrm{c}$ & $100 \mathrm{a}$ & $8.78 \mathrm{~d}$ & $25.39 \mathrm{~d}$ & $100 \mathrm{a}$ & $9.42 \mathrm{c}$ & $28.39 \mathrm{~d} 100 \mathrm{a}$ & 10.75 c 29.97 e 100 a & $11.67 \mathrm{c}$ & $33.55 \mathrm{f}$ & $100 \mathrm{a}$ \\
\hline IAN 2880 & $7.08 \mathrm{~b}$ & $19.65 \mathrm{~b}$ & $100 \mathrm{a}$ & $7.80 \mathrm{~b}$ & $22.79 \mathrm{c}$ & $100 \mathrm{a}$ & $9.09 \mathrm{c}$ & $26.44 \mathrm{~d}$ & $100 \mathrm{a}$ & $9.99 \mathrm{~b}$ & $29.44 \mathrm{~d} 100 \mathrm{a}$ & $11.23 \mathrm{c} 31.21 \mathrm{e} 100 \mathrm{a}$ & $12.08 \mathrm{c}$ & $34.72 \mathrm{e}$ & $100 \mathrm{a}$ \\
\hline PR 107 & $7.29 \mathrm{~b}$ & $19.23 \mathrm{~b}$ & $100 \mathrm{a}$ & $7.75 \mathrm{~b}$ & $23.46 \mathrm{c}$ & $91.67 \mathrm{c}$ & $9.37 \mathrm{c}$ & $27.08 \mathrm{~d}$ & $91.67 \mathrm{c}$ & $10.39 \mathrm{~b}$ & $30.40 \mathrm{c} 91.67 \mathrm{c}$ & $11.24 \mathrm{c} 33.24 \mathrm{~d} 91.67 \mathrm{c}$ & $12.46 \mathrm{c}$ & $36.09 \mathrm{e}$ & $91.67 \mathrm{c}$ \\
\hline GT 1 & $7.83 \mathrm{a}$ & $18.21 \mathrm{~b}$ & $100 \mathrm{a}$ & $8.66 \mathrm{a}$ & $22.90 \mathrm{c}$ & $100 \mathrm{a}$ & $\begin{array}{l}10.68 \\
\mathrm{a}\end{array}$ & $25.71 \mathrm{~d}$ & $100 \mathrm{a}$ & $11.92 \mathrm{a}$ & $28.17 \mathrm{~d} 100 \mathrm{a}$ & 12.73 a 30.22 e $100 \mathrm{a}$ & $14.21 \mathrm{a}$ & $32.93 \mathrm{f}$ & $100 \mathrm{a}$ \\
\hline
\end{tabular}

${ }^{1} \mathrm{H}=$ Height average;

${ }^{2} \mathrm{C}=$ Stem circumference average;

${ }^{3} \mathrm{~S}=$ Survival percentage.

Different letters in the column indicate difference between the averages through Scott-Knott test $(\mathrm{P} \leq 0.05)$.

trees suitable for bleeding. The low potential of the clone IAN 2880 was also observed by this author, with no tree suitable for bleeding. The circumference annual current and mean increments, referring to the evaluation periods refers to an immaturity period, because the clones, until the $128^{\circ}$ month, had not been bled (Table 4). The variation of circumference increments before and after bleeding, in immature and adult periods of rubber plantation is an important characteristic in the maintenance of stable production.

Table 3 - Percentage of rubber trees (Hevea brasiliensis (Willd. ex A. Juss.) Müell.Arg.) suitable for bleeding with circumference equal or higher than $45 \mathrm{~cm}$, related to the studied clones and evaluation time in Paracatu, MG.

\begin{tabular}{|c|c|c|c|c|c|c|}
\hline \multirow{2}{*}{ Clones } & \multicolumn{6}{|c|}{ Bleeding percentages in the following ages-- } \\
\hline & 62 months & 77months & 87months & 99months & 113 months & 128months \\
\hline IAN 3193 & $0.00 \mathrm{a}$ & $0.00 \mathrm{a}$ & $0.00 \mathrm{a}$ & $0.00 \mathrm{~b}$ & $0.00 \mathrm{c}$ & $8.33 \mathrm{~b}$ \\
\hline IPA 1 & $0.00 \mathrm{a}$ & $0.00 \mathrm{a}$ & $0.00 \mathrm{a}$ & $0.00 \mathrm{~b}$ & $0.00 \mathrm{c}$ & $4.17 \mathrm{~b}$ \\
\hline IAC 15 & $0.00 \mathrm{a}$ & $0.00 \mathrm{a}$ & $0.00 \mathrm{a}$ & $0.00 \mathrm{~b}$ & $0.00 \mathrm{c}$ & $20.83 \mathrm{~b}$ \\
\hline PB 235 & $0.00 \mathrm{a}$ & $0.00 \mathrm{a}$ & $0.00 \mathrm{a}$ & $4.17 \mathrm{~b}$ & $8.33 \mathrm{~b}$ & $12.50 \mathrm{~b}$ \\
\hline PR 255 & $0.00 \mathrm{a}$ & $0.00 \mathrm{a}$ & $0.00 \mathrm{a}$ & $4.17 \mathrm{~b}$ & $25.00 \mathrm{a}$ & $54.17 \mathrm{a}$ \\
\hline PR 107 & $0.00 \mathrm{a}$ & $0.00 \mathrm{a}$ & $0.00 \mathrm{a}$ & $8.33 \mathrm{~b}$ & $16.67 \mathrm{~b}$ & $20.83 \mathrm{~b}$ \\
\hline RRIM 600 & $0.00 \mathrm{a}$ & $0.00 \mathrm{a}$ & $0.00 \mathrm{a}$ & $8.33 \mathrm{~b}$ & $16.67 \mathrm{a}$ & $29.17 \mathrm{~b}$ \\
\hline IAN 2880 & $0.00 \mathrm{a}$ & $0.00 \mathrm{a}$ & $0.00 \mathrm{a}$ & $12.50 \mathrm{a}$ & $12.50 \mathrm{a}$ & $16.67 \mathrm{~b}$ \\
\hline IAN 3156 & $0.00 \mathrm{a}$ & $0.00 \mathrm{a}$ & $0.00 \mathrm{a}$ & $16.67 \mathrm{a}$ & $25.00 \mathrm{a}$ & $45.83 \mathrm{a}$ \\
\hline RRIM 701 & $0.00 \mathrm{a}$ & $0.00 \mathrm{a}$ & $4.17 \mathrm{a}$ & $16.67 \mathrm{a}$ & $29.17 \mathrm{a}$ & $33.33 \mathrm{a}$ \\
\hline GT 1 & $0.00 \mathrm{a}$ & $0.00 \mathrm{a}$ & $0.00 \mathrm{a}$ & $20.83 \mathrm{a}$ & 29.17 a & $41.67 \mathrm{a}$ \\
\hline IAN 3087 & $0.00 \mathrm{a}$ & $0.00 \mathrm{a}$ & $4.17 \mathrm{a}$ & $29.17 \mathrm{a}$ & $33.33 \mathrm{a}$ & $41.67 \mathrm{a}$ \\
\hline
\end{tabular}

Different letters in the column indicate difference between the averages through Scott-Knott test $(\mathrm{P} \leq 0.05)$. 
Table 4 - Annual current circumference increment (ICAC), annual mean circumference increment (IMAC) of rubber tree (Hevea brasiliensis (Willd. ex A. Juss.) Müell.Arg.) related to the studied clones and evaluation time in Paracatu, MG.

\begin{tabular}{|c|c|c|c|c|c|c|c|c|c|c|c|}
\hline \multirow[t]{2}{*}{ Clones } & \multirow{2}{*}{$\begin{array}{c}62 \\
\text { IMAC }\end{array}$} & \multicolumn{2}{|c|}{-------62-77------- } & \multicolumn{2}{|c|}{-------77-87------- } & \multicolumn{2}{|c|}{-------87-99-------- } & \multicolumn{2}{|c|}{-------99-113------- } & \multicolumn{2}{|c|}{-----113-128----- } \\
\hline & & ICAC & IMAC & ICAC & IMAC & ICAC & IMAC & ICAC & IMAC & ICAC & IMAC \\
\hline IAN 3156 & $4.25 \mathrm{~b}$ & $6.44 \mathrm{a}$ & $4.43 \mathrm{~b}$ & $4.46 \mathrm{a}$ & $4.54 \mathrm{a}$ & $4.67 \mathrm{a}$ & $4.55 \mathrm{a}$ & $3.72 \mathrm{a}$ & $4.38 \mathrm{a}$ & $4.14 \mathrm{a}$ & $4.26 \mathrm{a}$ \\
\hline IAC 15 & $3.80 \mathrm{c}$ & $3.15 \mathrm{~b}$ & $3.55 \mathrm{~d}$ & $3.65 \mathrm{a}$ & $3.65 \mathrm{~d}$ & $3.00 \mathrm{~b}$ & $3.57 \mathrm{~d}$ & $1.78 \mathrm{~b}$ & $3.32 \mathrm{e}$ & $3.50 \mathrm{a}$ & $3.26 \mathrm{~d}$ \\
\hline PR 255 & $4.04 \mathrm{~b}$ & $7.04 \mathrm{a}$ & $4.36 \mathrm{~b}$ & $5.77 \mathrm{a}$ & $4.65 \mathrm{a}$ & $5.21 \mathrm{a}$ & $4.72 \mathrm{a}$ & $3.30 \mathrm{a}$ & $4.48 \mathrm{a}$ & $4.28 \mathrm{a}$ & $4.36 \mathrm{a}$ \\
\hline IAN 2880 & $4.08 \mathrm{~b}$ & $5.07 \mathrm{a}$ & $4.08 \mathrm{c}$ & $4.06 \mathrm{a}$ & $4.17 \mathrm{~b}$ & $4.52 \mathrm{a}$ & $4.21 \mathrm{~b}$ & $2.26 \mathrm{~b}$ & $3.93 \mathrm{c}$ & $2.90 \mathrm{a}$ & $3.74 \mathrm{c}$ \\
\hline IP A1 & $3.52 \mathrm{c}$ & $4.69 \mathrm{a}$ & $3.57 \mathrm{~d}$ & $2.81 \mathrm{a}$ & $3.55 \mathrm{~d}$ & $2.46 \mathrm{~b}$ & $3.42 \mathrm{~d}$ & $2.05 \mathrm{~b}$ & $3.21 \mathrm{e}$ & $2.71 \mathrm{a}$ & $3.09 \mathrm{~d}$ \\
\hline PR 107 & $3.92 \mathrm{c}$ & $5.92 \mathrm{a}$ & $4.08 \mathrm{c}$ & $3.00 \mathrm{a}$ & $4.03 \mathrm{c}$ & $4.45 \mathrm{a}$ & $4.08 \mathrm{~b}$ & $2.29 \mathrm{~b}$ & $3.82 \mathrm{c}$ & $3.42 \mathrm{a}$ & $3.69 \mathrm{c}$ \\
\hline RRIM 600 & $4.08 \mathrm{~b}$ & $3.38 \mathrm{~b}$ & $3.81 \mathrm{~d}$ & $3.76 \mathrm{a}$ & $3.89 \mathrm{c}$ & $3.78 \mathrm{~b}$ & $3.88 \mathrm{c}$ & $2.00 \mathrm{~b}$ & $3.61 \mathrm{~d}$ & $2.99 \mathrm{a}$ & $3.47 \mathrm{c}$ \\
\hline RRIM 701 & $4.27 \mathrm{~b}$ & $5.62 \mathrm{a}$ & $4.32 \mathrm{~b}$ & $3.47 \mathrm{a}$ & $4.30 \mathrm{~b}$ & $3.14 \mathrm{~b}$ & $4.16 \mathrm{~b}$ & $1.54 \mathrm{~b}$ & $3.81 \mathrm{c}$ & $2.26 \mathrm{a}$ & $3.57 \mathrm{c}$ \\
\hline PB 235 & $3.85 \mathrm{c}$ & $2.76 \mathrm{~b}$ & $3.53 \mathrm{~d}$ & $2.74 \mathrm{a}$ & $3.50 \mathrm{~d}$ & $3.01 \mathrm{~b}$ & $3.44 \mathrm{~d}$ & $1.58 \mathrm{~b}$ & $3.18 \mathrm{e}$ & $3.59 \mathrm{a}$ & $3.15 \mathrm{~d}$ \\
\hline GT 1 & $4.66 \mathrm{a}$ & $5.90 \mathrm{a}$ & $4.67 \mathrm{a}$ & $3.44 \mathrm{a}$ & $4.61 \mathrm{a}$ & $4.10 \mathrm{a}$ & $4.55 \mathrm{a}$ & $1.85 \mathrm{~b}$ & $4.18 \mathrm{~b}$ & $3.34 \mathrm{a}$ & $4.00 \mathrm{~b}$ \\
\hline IAN 3193 & $3.72 \mathrm{c}$ & $4.23 \mathrm{~b}$ & $3.66 \mathrm{~d}$ & $3.62 \mathrm{a}$ & $3.73 \mathrm{~d}$ & $3.32 \mathrm{~b}$ & $3.69 \mathrm{c}$ & $2.84 \mathrm{a}$ & $3.53 \mathrm{~d}$ & $2.85 \mathrm{a}$ & $3.39 \mathrm{~d}$ \\
\hline IAN 3087 & $4.36 \mathrm{~b}$ & $3.11 \mathrm{~b}$ & $3.99 \mathrm{c}$ & $4.64 \mathrm{a}$ & $4.18 \mathrm{~b}$ & $4.73 \mathrm{a}$ & $4.24 \mathrm{~b}$ & $4.18 \mathrm{a}$ & $4.16 \mathrm{~b}$ & $4.60 \mathrm{a}$ & $4.11 \mathrm{~b}$ \\
\hline
\end{tabular}

Different letters in the column indicate difference between the averages through Scott-Knott test $(\mathrm{P} \leq 0.05)$.

Generally, circumference increments are significantly smaller in adult phase, when compared to immature period, indicating possibility of reduction in stem growth due to latex exploitation (GONÇALVES et al., 2001, GONÇALVES et al., 2006).

It can be observed that clones GT 1, IAN 3156 e PR 255 were more vigorous, with higher annual growth averages in the period. Even so, the observed values are lower than the ones reported by GONÇALVES et al. (2006), whose most vigorous clones exceeded $7 \mathrm{~cm}$ in the immature period, verifying that the clones GT 1, PR 255, PB 235 e RRIM 701 also presented higher inclement in stem circumference, exceeding $8 \mathrm{~cm}$, throughout the whole immature period, with a increment peak in the third to fourth year growth.

In São Paulo State, clone IAN 3156 was highlighted for presenting high stem circumference mean increment in immature stage, up to eight years growth, averaging 6,96cm (GONÇALVES et al., 2001). Some authors observed higher increment in the beginning of population development, from the third to sixth year after plantation (GONÇALVES et al., 2001; GONÇALVES et al., 2006), what suggests that the maximum circumference increment for some clones may have happened in earlier periods than the one presented in this research.

\section{CONCLUSION}

In this experiment's culture conditions evaluated from 62 to 128 months, the clones GT 1, IAN 2880, IAC 15, RRIM 600, PB 235 e IAN 3156 presented the best establishment potential; PR 255 e IAN 3156 presented the best stem circumference growth, PR255 was the first to reach minimum limit of $50 \%$ bleeding suitable trees, at 128 months age, in the studied region. Circumference and height growth over the evaluated period evidences that the studied rubber tree clones presented different growth rates in the region of Paracatu, MG.

\section{REFERENCES}

ALVES, R.M. et al. Behaviour of some amazonian clones of rubber tree in Tracuateua. Pesquisa Agropecuária Brasileira, Brasília, v.17, n.10, p.1465-1470, 1982. Available from: <http://seer.sct. embrapa.br/index.php/pab/article/view/16323/10535>. Accessed: Apr. 12, 2012. doi:1678-3921/1465-1470.

CAVAlCANTE, J.R; CONFORTO, E.C. Performance of five young clones of rubber tree in the São Paulo Occidental plateau region. Bragantia, Campinas, v.61, n.3, p.237-245, 2002. Available from: $\quad<$ http://dx.doi.org/10.1590/S0006-87052002000300005>. Accessed: Sept. 25, 2015. doi:10.1590/S0006-87052002000.300005.

CONFORTO, E.C. et al. Initial development of IAC rubber clones in São José do Rio Preto, São Paulo State, Brazil. Ciência Rural, Santa Maria, v.45, n.7, p.1235-1240, 2015. Available from: <http:// dx.doi.org/10.1590/0103-8478cr20120443>. Accessed: Sept. 25, 2015. doi: 10.1590/0103-8478cr20120443.

FERREIRA, D.F. Sisvar: a computer statistical analysis system. Symposium, Lavras, v.6, p.36-41, 2010. Available from: <http:// dx.doi.org/10.1590/S1413-70542011000600001>. Accessed: Jan. 28, 2013. doi: 10.1590/S1413-70542011000600001.

FURTADO, E.L. Manejo do mal das folhas de seringueira no Brasil. Informe agropecuário, Belo Horizonte, v.28, n.237, p.88-94, 2007. 
GONÇALVES, P.S. et al. Performance of new clones of hevea: III. potential selections for the plateau region of Votuporanga, São Paulo State, Brazil. Pesquisa Agropecuária Brasileira, Brasília, v.34, n.6, p.971-980, 1999. Available from: <http://dx.doi. org/10.1590/S0100-204X1999000600007>. Accessed: Jan. 05, 2013. doi: 10.1590/S0100-204X199900060000.

GONÇALVES, P.S. et al. Performance of Hevea clones from IAC 300 series selected in the northwestern region of São Paulo State, Brazil. Pesquisa Agropecuária Brasileira, Brasília, v.36, n.4, p.589-599, 2001. Available from: <http://dx.doi.org/10.1590/ S0100-204X2001000400001>. Accessed: Apr. 12, 2012. doi: 10.1590/S0100-204X2001000400001.

GONÇALVES, P.S. et al. Performance of Amazonian rubber tree clones in the plateau region of the State of São Paulo, Brazil. Pesquisa Agropecuária Brasileira, Brasília, v.36, n.12, p.14691477, 2001a. Available from: <http://dx.doi.org/10.1590/S0100204X2001001200004>. Accessed. 12, 2012. doi: 10.1590/S0100$204 X 2001000400001$.

GONÇALVES, P.S. et al. Performance of IAC 300 rubber clones in the plateau of São Paulo State, Brazil. Pesquisa Agropecuária Brasileira, Brasília, v.37, n.2, p.131-138, 2002. Available from: <http://dx.doi.org/10.1590/S0100204X2002000200003>. Accessed: Dec. 08, 2013. doi: 10.1590/ S0100-204X2002000200003.

GONÇALVES, P.S. et al. Genotype-environment interaction and phenotypic stability for girth growth and rubber yield of Hevea clones in São Paulo State, Brazil. Genetics and Molecular Biology, São Paulo, v.26, n.4, p.441-448, 2003. Available from: $<$ http://www.scielo.br/pdf/gmb/v26n4/a07v26n4.pdf>. Accessed: Sept. 20, 2015. doi: 10.1590/S1415-47572003000400007.

GONÇALVES, P.S. et al. Phenotypic expression of rubber tree clones in the northwestern region of São Paulo state. Bragantia, Campinas, v.65, n.3, p.389-398, 2006. Available from: <http:// dx.doi.org/10.1590/S0006-87052006000300004>. Accessed: Feb. 27, 2012. doi: 10.1590/S006-87052006000300004.

IBGE. Produção da Extração vegetal e da Silvicultura 2011. Rio de Janeiro, 2012. v.26, p.1-55.
MACEDO, R.L.G. et al. Introduction of hevea clones in the northwest of Minas Gerais state. Cerne, Lavras, v.8, n.1, p.124-133, 2002. Available from: <http://www.redalyc.org/articulo.oa?id=74408112>. Accessed: Apr. 10, 2012. doi: 0104-7760/74408112.

MACEDO, R.L.G. et al. Establishment and development of hevea spp. clones in Paracatu region, Minas Gerais. Cerne, Lavras, v.15, n.1, p.84-91, 2009. Available from: <http://www.redalyc.org/ articulo.oa? $\mathrm{id}=74413015011>$ Accessed: Apr. 23, 2012.doi:01047760/74413015011.

MESQUITA, A.C. et al. Sazonal production and latex characteristics in rubber tree (Hevea brasiliensis Muell. Arg.) clones in Lavras, State of Minas Gerais, Brazil. Bragantia, Campinas, v.65, n.4, p.633-639, 2006. Available from: <http:// dx.doi.org/10.1590/S0006-87052006000400014>. Accessed: Sept. 25, 2015. doi:10.1590/S0006-87052006000400014.

PEREIRA, A.V. et. al. Cultura da seringueira no Cerrado. Planaltina: Embrapa Cerrados, 2001. 59p.

ROSSMANN, H. et al. Borracha: longe da auto-suficiência. Agroanalysis (FGV), São Paulo, v.25, n.7, p.41-42, 2005. Available from: <http://bibliotecadigital.fgv.br/ojs/index.php/ agroanalysis/article/view/51373/50147>. Accessed: Sept. 24, 2015. doi: 0100-429851373/50147.

SAA. Comissão Técnica da Seringueira. A cultura da seringueira para o Estado de São Paulo. 2.ed. Campinas: CATI, 2010. 163p. (Manual Técnico, 72).

STEEL. R.G.D.et al. Principles and procedures of statistics. New York: McGraw-Hill, 1977. 633p.

VERARDI, C.K. et al. Adaptability and stability of rubber production and selection in rubber tree progenies. Pesquisa Agropecuária Brasileira, Brasília, v. 44, n.10, p.1277-1282, 2009. Available from: $\quad<$ http://dx.doi.org/10.1590/S0100-204X2009001000010>. Accessed: Sept. 23, 2015. doi: 10.1590/S0100-204X2009001000010.

VILELA, D. et al. Contribuições das câmaras setoriais e temáticas à formulação de políticas públicas e privadas para 0 agronegócio. Brasília: MAPA/SE/CGAC, 2006. 496p. 